\title{
心拍変動増大が圧反射感度と随伴性陰性変動に及ぼす影響
}

\author{
$\bigcirc$ 榊原雅人 \\ (愛知学院大学心身科学部心理学科) \\ キーワード : 心拍変動, 圧受容体反射, 随伴性陰性変動
}

Effect of increased heart rate variability on baroreflex sensitivity and contingent negative variation

Masahito SAKAKIBARA

(Department of Psychology, Aichi Gakuin University)

Key words: heart rate variability, baroreflex, contingent negative variation

目的

ペース呼吸とバイオフィードバックによって心拍変動 (HRV)を増大させる技法(HRVBF)はストレスに関わるさまざ まな症状(抑うつ, 不安, 不眠など)を緩和することが報告され ている。この臨床効果の背景には心拍変動の増大に伴う圧受 容体反射機能の改善が指摘されているが(Lehrer et al., 2003), 一方で HRVBF が皮質活動に与える影響については詳しく検 討されていない。随伴性陰性変動(CNV)は注意や期待に関わ る皮質活動の指標とされ, 圧受容体反射感度と相関すること が報告されている(Duschek et al., 2013)。本研究は HRVBF によ って心拍変動を増大させたとき, 圧受容体反射感度の高まり と共に CNV が変化するかどうか検討した。

\section{方 法}

参加者 健常な男女大学生 12 名(18〜21 歳)が参加した(本 研究は愛知学院大学研究倫理委員会の承認を受けた)。

装置 脳波は $\mathrm{Fz}, \mathrm{Cz}, \mathrm{Pz}$ から記録した(両耳架基準電極，時 定数 5 秒，サンプリング $1.5 \mathrm{KHz})$ 。また、右眼窩下部 $1 \mathrm{~cm}$ に 電極を配置し眼電図を記録した。これらの生理反応は生体用 アンプ(MA1000, デジテックス研究所)にて増幅し、刺激呈示 トリガ信号とともにデータレコーダ(LX-10, TEAC)に記録し た。また, 心電図は $\mathrm{CM}_{5}$ 誘導にて増幅記録し(BA1008, デジテ ックス研究所), 呼吸はストレンゲージを用いて測定した。さ らに、左手第 2 または 3 指から連続血圧(CNAP500, Cnsystem) を測定した。

$\mathrm{HRV}$ 増大課題 モニタ画面に呼吸調整用の棒グラフイメ ージ(縦横 $3 \times 1 \mathrm{~cm})$ を呈示した。棒グラフは上昇/下降するよう にプログラムされており，上昇に合わせて吸気を，下降に合 わせて呼気を行うよう指示した。ペース呼吸の周波数は安静 時の心拍変動を解析した結果にもとづき, 当該参加者の心拍 変動低周波帯(LF, 0.04-0.15 Hz)のピーク周波数とした(榊原・ 及川, 2017)。

$\mathrm{CNV}$ 課題 モニタ中央(参加者の眼前約 $1 \mathrm{~m}$ )に注視点 $(10 \times 10 \mathrm{~mm}$ の十字) を $1000 \mathrm{~ms}$ (直後 $500 \mathrm{~ms}$ の blank を挿入) 呈 示した後, 赤い円 $(10 \mathrm{~mm})$ を呈示した。この状態で予告信号と なる音刺激 $(1000 \mathrm{~Hz}, 500 \mathrm{~ms})$ を呈示し $(\mathrm{S} 1)$, その $3500 \mathrm{~ms}$ 後に 緑の円(同サイズ)を呈示した(S2)。この際，当該刺激に対する ボタン押し反応を求めた。これを一試行として試行間間隔を 8〜 16s として 60 回実施した。半数の試行を終えた時点で休 毠を入れボタン押しを利き手または非利き手に変更した。

手続き 生体センサ装着後 10 分間の順応期を設け，5 分間の 安静ベースラインを測定した。その後, 心拍変動増大課題を 20 分間(5 分 $\times 4$ 回)実施する HRV 条件, または, 風景映像(動 画)を 20 分間視聴する Control 条件を行った。これらの条件の 後, 血圧, 呼吸センサを解除し, 参加者は約 $50 \mathrm{~cm}$ 後方に設置 された CNV 課題用机一座位のまま回転移動し CNV 課題を実 施した。すべての参加者は HRV 条件と control 条件を日を替 えてランダムに実施した。
分析 はじめに心電図 $R R$ 間隔を $m s$ 単位で計測し, 心拍変 動増大の程度を検討するため各測定期における SDNN (正常 な心拍 RR 間隔の標準偏差)を求めた。圧受容体反射感度は Spontaneous sequence 法によって評価した(Parlow et al., 1995)。 ここでは連続血圧・心電図データから，収縮期血圧と RR 間 隔が共に連続して増加/減少する系列(3〜7拍)を抽出しそれら の回帰係数を算出して平均した。脳波データは S1 呈示前 $200 \mathrm{~ms}$ から S2 呈示後 500ms の区間を加算平均し, 初期 CNV(S1 呈示後 600-1600ms), 後期 CNV(S1 呈示後 2500-3500ms), 総 CNV(600-3500ms)の面積を求めた。

\section{結果と考察}

Table 1 は各条件における SDNN を示している。Control に 比較して HRV 条件では 4 回の測定を通じて明確に心拍変動 が増大していることがわかる。 BSL から S4 における圧反射 感度は HRV 条件が 10.3 から $18.2 \mathrm{~ms} / \mathrm{mmHg}$, Control 条件が 13.2 から $11.7 \mathrm{~ms} / \mathrm{mmHg}$ となった(交互作用: $p<.005$ )。

Table1 各条件における $\operatorname{SDNN}( \pm \mathrm{SE})$

\begin{tabular}{|c|c|c|c|c|}
\hline BSL & S1 & S2 & S3 & S4 \\
\hline HRV 条件 $65 \pm 6$ & $106 \pm 6$ & $111 \pm 5$ & $104 \pm 5$ & $109 \pm 6$ \\
\hline Control 条件 $59 \pm 5$ & $72 \pm 5$ & $78 \pm 7$ & $78 \pm 5$ & $80 \pm 5$ \\
\hline
\end{tabular}

Fig.1 は Czにおける総加算波形である。HRV 条件の振幅は control 条件に比べて S2 呈示前で増加するようにみえたが CNV の各指標に有意差はみられなかった。今後, 参加者数を 増してさらに検討を継続する予定である。

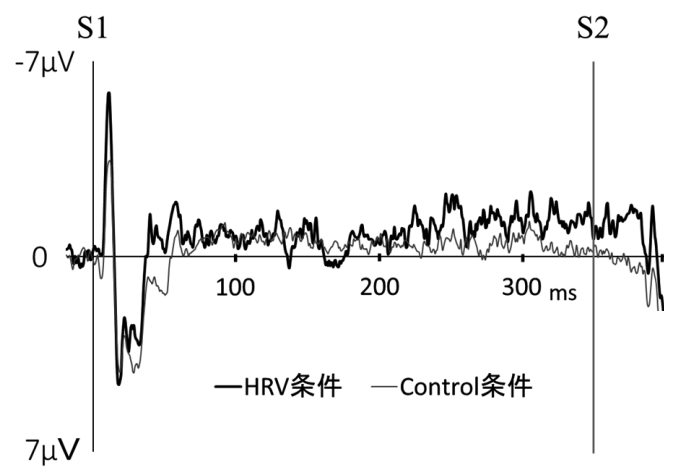

Fig.1. Czにおける CNV 波形

本研究は科研費 No.16K04395 の補助を受けた。 